\title{
EXPERIMENTELLE EINFÜHRUNG
}

\author{
IN DIE \\ UNORGANISCHE CHEMIE \\ VON
}

\section{HEINRICH BILTZ}

MIT FƯNFZEHN FIGUREN

VIERTE AUFLAGE

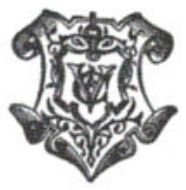

LEIPZIG

VERLAG VON VEIT \& COMP. 
Der Verfasser behält sich das Recht der Ứbersetzung vor.

Druck von Metzger \& Wittig in Leipzig 